\title{
Mesenchymal Stem Cell-Based Bone Engineering for Bone Regeneration
}

\author{
Mohamadreza Baghaban Eslaminejad and Faezeh Faghihi \\ Department of Stem Cell and Developmental Biology, \\ Royan Institute for Stem Cell Biology and Technology, ACECR, Tehran
}

Iran

\section{Introduction}

Many people worldwide suffer from bone defects due to trauma or disease. About $5-10 \%$ of football injury-related bone fractures, in addition to bone tumor resection and massive traumatic bone loss result in critical-sized bone defects that cannot regenerate autonomously (Cattermole et al., 1996; Low et al., 2004; Reuss et al., 2007 as cited in Porter et al., 2009). Usually small bone defects heal spontaneously but large defects cannot regenerate without intervention. There are several options for the reconstruction of large bone defects that include bone grafts (autograft, allograft and xenograft) as well as bone constructs created by bone tissue engineering principles.

Among these different strategies, bone grafts from healthy donors have been used as therapies for decades, but nowadays they are used less due to inherent limitations associated with their application. For example, autografts are usually obtained from the iliac crest (Porter et al., 2009) and have been used in clinics for a long time. However some disadvantages, including supply limitation, risk of donor site morbidity, pain, paresthesia, hematoma and inflammation, as well as the need for prolonged rehabilitation (For review see Heary et al., 2002; Krelow et al., 2007; Maddela et al., 2010; Nakajima et al., 2007) limit their applications. Allografts, on the other hand, are the other option that may be chosen for bone defect regeneration. This type of bone graft can be derived from viable or sterilized non-viable (cadaver) human sources. Orthopedic allografts exhibit certain drawbacks by transmitting donor pathogens to the recipient body and triggering host immune responses (For review see Hou et al., 2005 and Nishida et al., 2008). Xenografts obtained from nonhuman sources may be considered as the other alternative for reconstructing bone defects, but this is a last resort which may be taken because it is not an approved option in transplantation, owing to the obvious risk of viral and disease transmission, infection, toxicity and immunogenicity as well as rejection by the recipient's body (For review see Laurencin et al., 2008; Yang et al., 2007).

Concerns associated with applications of bone graft for critical size bone defects have challenged scientists to search for suitable options. Attempts to replace appropriate substitutes for bone graft have resulted in opening a new window in modern regenerative biomedicine and the emergence of bone constructs elaborated by tissue engineering principles. The term tissue engineering is defined as the application of the principles and 
methods of engineering and life science toward fundamental understanding of structurefunction relationship in normal and pathological mammalian tissues and the development of biological substitutes for the repair or regeneration of tissue or organ function (Persidis 1999; Chapekar et al., 2000). To develop biologic substitute tissue engineering uses three building blocks including scaffold, cells and growth factors. Each of these elements alone can promote tissue regeneration but constructs fabricated with the use of component combination would be more effective. The objective of the present chapter is therefore to describe bone construct fabricated with tissue engineering principles for bone regeneration. Among cellular candidates, mesenchymal stem cells (MSCs) possess some characteristics that make them more appropriate for bone tissue engineering. Hence, the focus of the current chapter is MSC-based bone constructs.

\section{Mesenchymal stem cells as cellular candidates for bone engineering}

Bone constructs typically consist of three elements: scaffolds, growth factors and cells. Several cell types can potentially be used as cellular material for elaborating a bone construct. In this section, commonly used cells with potential applications in the field of bone engineering will be summarized, followed by special focus on MSCs.

\subsection{Osteoblastic cells}

Osteoblastic cells may seem to be more appropriate for bone engineering because they are resident cells in natural bone and can be utilized at autogenic settings. In bone engineering strategies, osteoblastic cells are usually obtained from biopsies taken autologously from patient's bone. Despite of this obvious advantage, there are some concerns with the use of osteoblasts in the process of bone engineering. Osteoblasts are present in limited numbers in bone biopsies since bone is indeed a tissue rich in ECM rather than cells. Furthermore, tissue engineering strategies need considerable cell numbers, however osteoblast proliferation is slow (Bruder et al., 1999; Heath et al., 2000). For these reasons stem cells having enormous proliferative capacity are preferable.

\subsection{Embryonic stem cells}

Embryonic stem cells (ESCs) are pluripotent cells derived from a blastocyst inner cell mass. Murine ESCs were described in 1981 (Evans et al., 1981) and human ESCs introduced in 1998 (Thomson et al., 1998). Their indefinite self-renewal potential, differentiation capacity to all three germ layers, and osteoblastic cells in particular ( Arpornmaekilong et al., 2009; Hwang et al., 2009a; Warotayanont et al., 2009 as cited in Seong et al., 2010) have persuaded scientists that ESCs could be appropriate for clinical applications. ESCs have the characteristics of self-renewal as long as they are exposed to a feeder cell layer or leukemia inhibitory factor (LIF). Differentiation initiates upon removal of the feeder cell layer or LIF, resulting in the formation of three dimensional cell aggregates known as embryoid bodies (EBs). These EBs can regionally differentiate into derivatives of three germ layers: mesoderm, ectoderm and endoderm (Itskovitz-Eldor et al., 2000 as cited in Seong et al., 2010). Generally, for osteogenic induction of ESCs, EBs or single cells from EBs are replated and induced by beta-glycerophosphate, ascorbic acid and vitamin D3 (Buttery et al., 2001; Kawaguchi et al., 2005; Woll et al., 2006 ). Thus ESCs can be a potential stem cell source to fabricate bone-like tissue constructs in the field of tissue engineering; however, 
immunologic incompatibility and the possibility of teratoma formation in transplantations as well as certain ethical concerns make scientists hesitant to use them as cellular materials with which to fabricate bone construct for bone regeneration (Undale, 2009).

\subsection{Induced pluripotent stem cells}

Because of the above-mentioned concerns regarding ESCs, scientists have tried to establish ESC-like stem cells, known as induced pluripotent stem cells (iPSCs) from somatic cells by plasmid or adenovirus-based transduction ( Takahashi and Yamanaka, 2006, Park et al., 2008, Kang et al., 2009 as cited in Feng et al., 2010). Actually, iPSCs are patient-specific ESCs without ethical concerns that do not trigger an immune response (Feng et al., 2010). The differentiation potential of these cells into various cell lineages, such as neural cells, cardiomyocytes and hematopoetic cells as well as osteoblasts have been confirmed (Hanna et al., 2007; Wernig et al., 2007). Despite this prominent capability, there is an important issue which needs to be considered before their clinical applications. The method by which iPSCs are generated, i.e. through plasmid or adenovirus-based transduction is a main concern.

\subsection{Mesenchymal stem cells}

Among stem cells, mesenchymal stem cells (MSCs) seem to be more suitable for bone engineering compared to ESCs, iPSCs or osteoblastic cells due to several characteristics that they possess. First, the osteogenic differentiation potential of MSCs is the first differentiation capacity reported at the time MSCs were discovered. Today, it is one of the most obvious characteristics of MSCs which is maintained for an extended time. Secondly, autologous MSCs are easily accessible from patient's multiple tissues, including bone marrow aspirates. Additionally, because of MSCs ability to modulate immune responses, the use of allogeneic MSCs may be feasible without a substantial risk of immune rejection (Undale et al., 2009).

\subsubsection{Characteristics of MSCs}

MSCs are defined as non-hematopoietic cells derived from bone marrow as well as other mesenchmal tissues. These cells possess two important capacities: the potential to self-renew for a relatively long time and the ability to differentiate along multiple cell lineages including bone, cartilage and adipose cells. MSCs express many surface antigens including STRO-1, CD105, SH3, CD29, CD44, CD71, CD90, CD106 and CD124 (for review see Pittenger et al., 1999; Colter et al., 2001). Besides bone marrow, multiple tissues have been reported to contain MSCs including adipose tissue (Dragoo et al., 2003), trabecular bone (Noth et al., 2002), periosteum (Fukumoto et al., 2003), synovial membrane (Wickham et al., 2003), skeletal muscle (Jankowsk et al., 2002), as well as teeth (Miura et al., 2003).

Cohnheim, a German pathologist, initially suggested the presence of MSCs when he attempted to study wound healing in rabbits. By intravenous injection of non-soluble aniline stain, Cohnheim could detect some stained cells at the site of the wound which had been experimentally created in the animal's distal limb. He concluded that the stained fibroblastic cells were derived from bone marrow and transferred to the wound site via the circulatory system (Prockop, 1997; Ross, et al., 1970). Since then, experimental studies on bone marrow transplantation have confirmed the osteogenic and chondrogenic differentiation capacities of bone marrow cells, but no one could clearly indicate the exact responsible cell types (Friedenstein et al., 1966; Petrakova et al., 1963). Finally, Friedenstein et al. have determined that the osteo/chondrogenic differentiation potential of bone marrow is due to the existence 
of a fibroblastic population referred to as colony forming unit-fibroblasts (Friedenstein et al., 1973). Thus far, these fibroblast-like cells have been referred to as marrow stromal cells; marrow progenitor cells (MPCs) and marrow stromal fibroblasts (MSFs), as well as mesenchymal stem cells (MSCs). MSC is the more frequently used nomination particularly in recently published investigations.

MSCs occur in low quantity in bone marrow aspirate and constitute approximately $0.001 \%$ $0.01 \%$ of the entire bone marrow cells. In spite of their limited numbers, MSCs can easily be expanded through standard culture techniques. The expansion of these cells is strongly dependent on the bovine serum content of the culture media. The cells assume spindlyshaped morphology upon cultivation. MSCs primary culture has been reported to be heterogeneous and contains multiple colonies with various differentiation capacities. Pittenger et al., in 1999, have shown that nearly one third of these colonies have osteogenic, adipogenic and chondrogenic differentiation potentials and the other two thirds exhibit either bipotent or unipotent capacity to differentiate into osteogenic/chondrogenic and adipogenic lineages, respectively (Pittenger et al., 1999). In addition to differentiating into bone, cartilage and adipose cells, MSCs have been reported to possess differentiation capacity along non-mesenchymal cell lineages such as neurons, keratinocytes, liver, intestine and kidney epithelial cells (for review see Sugaya 2003; Chapel et al. 2003). This property is referred to as MSCs plasticity or transdifferentiation.

\subsubsection{Osteogenic differentiation potential of MSCs}

Osteogenic differentiation of MSCs is a complex process in which various environmental factors are involved. Dexamethasone, ascorbic acid and beta glycerol phosphates are the most commonly used chemicals that promote in vitro osteogenic differentiation of MSCs. Among these compounds, dexamethasone plays a pivotal role such that in its absence, no differentiation occurs in human MSC culture (Porter et al., 2003). Ascorbic acid, on the other hand, has been found to be an important but not necessary component of osteogenic medium. The addition of ascorbic acid into osteogenic medium results in enrichment of the deposited matrix with collagen (Choi et al., 2008). Beta glycerol phosphate, as a phosphate enriched organic compound, plays some role in matrix mineralization (Coelho et al., 2000). Besides these three routinely used compounds, hormones and growth factors have osteogenic effects on MSCs differentiation. These include 1, 25-di-hydroxyvitaminD3 (vitD3) (Rickard et al., 1995), estrogen (Holzer et al., 2002), leptin and parathyroid hormone (Holzer et al., 2002), prostaglandin E2 (Scutt et al., 1995), sonic hedgehog (Spinella-Jaegles et al., 2001), IGF-1 (Koch et al., 2005), BMP-2, 4, 6, 7 (Gori et al., 1999; Diefenderfer et al., 2003; Gruber et al., 2004), FGF (Jaiswal et al., 2000), as well as bio- and lithium chloride (de Boer et al., 2004; Eslaminejad et al., 2008).

Each osteogenic factor inserts its effect through a distinct signaling pathway. Some of these pathways, such as the dexamethasone pathway, are unknown whereas others are recognized to some extent. For example, BMPs mediate their osteogenic effects through the BMP signaling pathway, via activation of smad transcription factors (Massague et al., 2000) and parathyroid hormone induces the expression of osteogenic genes via the G-protein coupled receptor signaling pathway (Carpio et al., 2001).

Induction of the above-mentioned signaling pathways ends consequently in expression of some specific signaling proteins and specific osteoblastic transcription factors. Core binding factor alpha 1 (Cbfa1), also referred to as Runx2, is the most important transcription factor 
involved in osteogenesis (Yamaguchi et al., 2000). This transcription factor induces the expression of different bone-related genes including osteocalcin, osteopontin, bone sialoprotein and the parathyroid hormone receptor (Ducy et al., 2000). Furthermore, osterix is the other transcription factor reported to be expressed upon commitment of cells toward osteogenic differentiation (Tu et al., 2006).

\subsubsection{Self-renewal in MSCs}

Self-renewal and differentiation potential are hallmarks for stem cells. The ability of a cell to produce similar replicates in a defined period of time via mitosis is called self-renewal. In this type of mitosis, genetic properties and karyotype of daughter cells remain intact, the same as the mother cell. There are two models that explain stem cell self-renewal property: symmetric and asymmetric cell division. In symmetric cell division, the stem cell divides into two daughter cells, similar to the mother cell, which have the capacity to differentiate under appropriate conditions (Potten and Loffler, 1990). In asymmetric cell division, each stem cell divides into one stem cell and one progenitor cell. The stem cell continues to divide and replenish the stem cell pool, while the progenitor cell differentiates under appropriate conditions (Sherely et al., 1995). Therefore, through this type of cell division, the number of stem cells remains intact.

While identification the underlying molecular mechanisms of MSCs self-renewal would be beneficial to stop replicative senescence in MSCs, this issue remains largely unknown. According to the literature, various cytokines and growth factors such as LIF (Jiang et al., 2002), FGFs (Zaragosi et al., 2006) and Wnt proteins (Kleber et al., 2004) have, however, some roles in keeping MSCs in a stemness state.

\subsubsection{Immunomodulatory properties of MSCs}

The immunomodulatory property of MSCs is one of the most considerable issues in the field of regenerative medicine. Numerous evidences exist on the suppressive effects of MSCs on immune cell activity. Co-culturing MSCs with T-lymphocytes results in the inhibition of T cell proliferation (Di Nicola et al., 2002). This effect is believed to be mediated by secretion of soluble factors that include interleukin 10, prostaglandins and hepatocyte growth factor as well as TGF-beta or via direct cell to cell contact ( for review see Bassi et al., 2011). Besides T-lymphocytes, MSCs insert their immunomodulatory effect by inhibition of B cell proliferation and antibody secretion (Rasmusson et al., 2007). Reportedly, they also suppress differentiation, maturation and activation of dendritic cells (Nauta et al., 2006 as cited in Bassi et al., 2011). Moreover, MSCs can suppress natural killer (NK) cell proliferation and change their phenotype, cytokine secretion and cytotoxic properties (Sotiropoulou et al., 2006). MSCs express an intermediate level of MHC class I, very low levels of MHC class II and do not express costimulatory molecules (Klyushnenkova et al., 2005).

Although the hypo-immunogenic properties of MSCs have roused medical interest to establish allogenic MSC banks for clinical application in the field of regenerative medicine, there remains one important question that must be taken into consideration: Do MSCs keep their immunomodulatory properties even after differentiation? Liu et al. have used MSCs from a rabbit model to answer this question (Liu et al., 2006). Their results have shown that osteogenic differentiated MSCs did not express MHC class II in vitro; however, transplantation of the differentiated cells makes these cells lose their immunomodulatory properties in vivo. 


\section{MSC-based bone constructs}

As mentioned, bone construct fabricated using scaffolds, cells and growth factors would be appropriate substitutes for bone grafts. Cells were previously described. In this part of the chapter, scaffolds and growth factors will briefly be considered and followed by some important issues in the field of bone engineering, including cell seeding onto scaffold, commonly-used bioreactors in bone engineering and the issue of the construct vascularity.

\subsection{Scaffolds}

Bone, as a dynamic and supportive tissue, is a nanocomposite structure. It is in fact a complex of well-organized inorganic-organic nanomaterials including hydroxyapatite [HA, Ca10 $\left.\left(\mathrm{Po}_{4}\right)_{6}(\mathrm{OH})_{2}\right)$ ] and collagen fibrils arranged in a masterly order (Maddela et al., 2010). Within this biomaterial composite, osteocytes lie in cavities referred to as lacunae. In bone tissue engineering, material scientists attempt to make biocompatible and biodegradable scaffolds with appropriate porosity, mechanical strength and hydrophobicity comparable to native bone materials (Lee et al., 2007 as cited in Maddela et al., 2010). Biocompatibility is the most important characteristic of scaffolds, which means that the scaffold material must not be toxic or promote inflammation upon transplantation. All scaffold degradation products should also be biocompatible. The scaffold must also be biodegradable meaning that it gradually degrades at the implantation site in harmony with bone regeneration in order to provide spaces for natural bone growth. Scaffold porosity is another characteristic that merits consideration in designing scaffolds. Incorporation of open and interconnective pores into the scaffold structure is essential in terms of cell growth and distribution, facilitation of vessel formation and diffusion of nutrient and waste products. The size of pores is recommended to be around 200-900 micrometers. If they are too small cells may adhere to the scaffold's superficial part. Large pore size, on the other hand, compromises scaffold strength. Since bone construct should be implanted at the defective bone site where it must temporary support the fracture, therefore bone scaffolds must possess mechanical properties comparable to native bone. The scaffold's surface property, in terms of chemical and topographical features, is a parameter that influences scaffold interaction with cells. Scaffolds must possess appropriate surfaces upon which cells can adhere, proliferate and differentiate.

Materials used to fabricate bone scaffolds include natural and synthetic bioceramics, natural and synthetic polymers and composites of polymers with bioceramics.

\subsubsection{Bioceramics}

There are two categories of bioceramics: naturally occurring (i.e., coral hydroxyappatite) and synthesized (i.e., synthetic hydroxyapatite and tricalcium phosphate). These materials are widely used in medical trials, orthopedics (for review see Block et al., 2000; Heini et al., 2001; Katti et al., 2004; Taksali et al., 2004 as cited in Habraken et al., 2010) and plastic surgery (Gladstone et al., 1995) due to their high mechanical strength and body response (Habraken et al., 2010). In particular, hydroxyapatite-based calcium phosphate compounds and bioactive glass are a focus of interest for bone engineering because they possess osteoconductive properties (LeGeros et al., 2002; Kenny et al., 2003). There are, however, several disadvantages that limit the application of bioceramics in the tissue engineering field. These materials possess low biodegradability and they bind strongly to growth factors 
such as bFGF and TGF- $\beta 3$, releasing them at very slow rates unsuitable for clinical applications (Habraken et al., 2010). Moreover, ceramics possess low tensile strength and are very brittle.

\subsubsection{Polymers}

As a whole, based on origin, polymers can be divided into two categories: natural and synthetic (Lee et al., 2007). The most widely used natural polymers in bone tissue engineering include collagen, alginate and chitosan. Collagen can be easily solubilized in physiological fluid (Lee et al., 2007; Maddela et al., 2010). Beside this advantage, immunogenecity, hard processing and the possibility of pathogen transmission are the most prominent disadvantages of natural polymers. Among natural polymers, collagen type I is very interesting since it is the pivotal organic component of bone matrix that is actively secreted by osteoblast cells (Lee et al., 2007). Although this protein in the form of a gel, nanofiber, porous scaffold and film is biocompatible, it cannot tolerate mechanical forces and consequently undergoes degradation at the implant site. Thus, natural polymers are rarely used alone.

Synthetic biodegradable polymers include polyglycolic acid (PGA), polylactic acid (PLA), polylactic-co-glycolic acid (PLGA), polycaprolacton (PCL), polypropylene fumarate (PPF), polycaprolacton fumarat and polycaprolacton diacrylate. Synthetic polymers are appropriate options as bone engineering scaffolds because they can be fabricated in large quantities, the risk of infection and toxicity is less compared to natural polymers. In addition, they possess less immunogenicity. Other advantages of synthetic polymers are their mechanical, physical, and chemical properties, elastic module, acidity and hydrophilicy which can easily be adjusted to match bone tissue. The disadvantages of synthetic polymers however include their very low strength that worsens with the introduction of pores to form tissue engineering scaffolds. Furthermore, most of these materials are considered non-osteoconductive (Behravesh et al., 1999; Middletone et al., 2000).

\subsubsection{Composite scaffolds}

The composite strategy has emerged with the purpose of seeking better scaffolds for bone tissue engineering. In this strategy, the objective is to combine bioceramic material with polymers to make use of the advantages of each biomaterial. In this manner, many polymerbased scaffolds that consist of bioactive bioceramics such as hydroxyapatite/PLLA have been produced (Zandi et al., 2010; Eslaminejad et al., 2007). In composite scaffolds, bioceramics serve to make the scaffold osteoconductive and provide reinforcement whereas the polymer serves to solve the problem of poor degradability, low tensile strength and brittleness of ceramics (Wang 2005).

\subsection{Growth factors}

Bone normal development involves a variety of hormones, cytokines and growth factors. These biomolecules regulate osteoprogenitor proliferation, migration and differentiation in a controlled manner (for review sees Kain et al., 2005, Schmidmaier et al., 2006). The following growth factors have been reported to play some role in bone differentiation; hence they can be used in bone engineering. 


\subsubsection{Bone morphogenetic protein}

Urist et al. in 1965 have reported that decalcified bone can induce the formation of ectopic bone; therefore they concluded that osteoinductive molecules could be present in the bone matrix and direct the differentiation of precursor cells into bone cells. Later these molecules were called bone morphogenetic proteins (BMPs) and are members of the TGF-beta superfamily. BMP-2, 4 and 7 are the main members of this category whit a considerable effect on the induction of bone formation (Kirker et al., 2000; Yoon et al., 2004).

\subsubsection{Insulin-like growth factor}

Insulin-like growth factor (IGF) induces proliferation and chemotactic migration of many types of cells. This growth factor has an important role in bone metabolism (Matsuda et al., 1992) especially at the time of fracture healing (Chen et al., 2006).

\subsubsection{Fibroblast growth factor}

The fibroblast growth factor (FGF) family has a conflicting role in osteogenesis and bone healing. While some authors have reported a positive effect of FGF-2 on bone healing (Kawaguchi et al., 1994; Kato et al., 1998), others have indicated that bFGF induces osteoclast formation (Nakagawa et al., 1999).

\subsubsection{Vascular endothelial growth factor}

This growth factor exerts its effects through induction of vascularization which in turn plays an important role in bone growth and development (Lee et al., 2007). Vascular endothelial growth factor (VEGF) also supports the survival and activity of bone-forming cells (Hsiong et al., 2000) as well as migration and differentiation of primary human osteoblasts (MayrWohlfart et al., 2002; Orlandini et al., 2006).

\subsubsection{Growth factor delivery in bone tissue engineering}

In order to have an efficient bone healing procedure, selection of suitable vehicles and types of bioactive molecules are crucial. There are two types of immobilization methods for binding of bioactive molecules to the carrier: non-covalent (physical entrapment, surface adsorption, affinity binding or ionic complexation) or covalent (chemical conjugation).

In bone engineering either polymeric or bioceramic carriers can be used to deliver growth factors to the site of the tissue defect. PLA and PGA are two well- known polymers of alphahydroxyl esters and copolymers of these monomers (PLGA) are good vehicles to carry osteoinductive factors (for review see Behravesh et al., 1999; Saito et al., 2001a, as cited in Lee et al., 2007). Calcium phosphate cement (CPC), bioactive glasses, HA and beta-TCP are non-polymeric, inorganic materials that have also been processed to deliver growth factors such as TGF, beta1 and BMPs (for review see Hedberg et al., 2005; Laffargue et al., 1999; Ripamonti et al., 1992).

The design of a delivery system, in the form of three-dimensional matrices, injectable gels, and micro/nano particulates determines release kinetics and stability of growth factors in constructs (Lee et al., 2007). Furthermore, physical structure and degradation time of polymers are important parameters to determine the release behavior of growth factors (Holland et al., 2006, as cited in Lee et al., 2007). 


\subsection{Cell seeding onto scaffold surfaces}

Bone construct is a term used to denote an engineered material that consists of different components, including scaffold/growth factors, scaffold/cells and scaffold/cells/growth factors. In the previous section incorporation of growth factor into the delivery vehicle (scaffold) was summarized. In the following sections, seeding of cells on scaffold surfaces - a crucial procedure in bone construct fabrication is discussed. Indeed, good cell-to-cell contact and acceptable dissemination of the cells within a scaffold are the results of an appropriate seeding procedure. These parameters have extensive impact on uniform welldeveloped bone tissue regeneration and mineralization after construct transplantation (Holy et al., 2000; Ishaug- Riley et al., 1998).

\subsubsection{Static cell seeding method}

Although the addition of the cell suspension onto a scaffold (static cell seeding system) is the most simple and frequently used method (Scaglione et al., 2008; Li et al., 2001), it is not a good approach for a well-elaborated bone construct with high cell density and homogenous cell distribution. This method is associated with a low seeding efficiency of approximately $10-25 \%$ (Roh et al., 2007) and a low rate of cell penetration inside the scaffold (Mo et al., 2004; Ravi et al., 2009; Ma, 2008). Even penetrated cells are unable to establish attachment with scaffold surfaces.

\subsubsection{Dynamic cell seeding}

Dynamic cell seeding process is a type of cell seeding usually performed with bioreactor systems. It can be categorized into two different systems: rotational seeding based on the use of hydrostatic forces (Hsu et al., 2005; Nasseri et al., 2003) or vacuum seeding using pressure differentials (van Wachem et al., 1990; Williams et al., 2004). Cell seeding yields by these techniques range from 38 to $90 \%$ and 60 to $90 \%$, respectively, compared to $10-25 \%$ for static seeding. Although the long seeding time in the rotational system and its bad impact on cell morphology limits its application, no adverse effects have thus far been reported for the vacuum seeding method (Gustavo et al., 2010).

\subsubsection{Magnetic cell seeding method}

Magnetic cell seeding is another technique proposed to efficiently incorporate cells inside scaffold porosity. This method involves the use of a magnetic force to attract magnetic nanoparticles attached to desired cells (Gustavo et al., 2010). There are two main approaches in this method. The first one involves the application of superparamagnetic monosized polymers such as dynabeads with the ability to bind specifically to a desired cell or protein and subsequent seeding of the cells in the scaffold by producing a temporary magnetic field. The efficiency of this method has been reported to be as much as 99\% (Perea et al., 2006; Tiwari et al., 2003, as cited in Gustavo et al., 2010). The second approach is to first label desired cells by cationic liposomes that contain superparamagnetic iron oxide particles, then seed them into a scaffold by the administration of a transient magnetic force. The efficiency of this protocol has been reported to be as high as 90\% (Ito et al., 2004; Shimizu et al., 2007 as cited in Gustavo et al., 2010). Rapid graft production and reproducible results are the main advantages of using this method in tissue engineering; albeit cell viability, cell morphology, as well as the fate of magnetic particles in the body and their adverse effects on other tissues need further evaluation (Gustavo et al., 2010). 


\subsection{Bioreactors}

Bioreactors, as containers or vessels, have long been used to hold microorganisms and different types of eukaryotic cells for the purpose of harnessing their natural biochemical processes in the production of drug and recombinant proteins. The main reason to use bioreactors in industry and medicine is the large scale production of desired products at an optimal level of gas, nutrients, temperature and tolerable amount of waste products for an extended period of time (Haasper et al., 2008). Bioreactors have also found some application in the bone tissue engineering field due to valuable advantages they offer toward producing optimal bone construct. Bioreactor systems help bone tissue engineering in several ways. The bioreactor cell culture process is automated. In this manner, the risks of cellular/ microbial contamination, labor intensity and laboratory costs during cell expansion and differentiation are minimized (Andrew et al., 2011). Furthermore, automated cell cultures have the advantages of improved cell seeding efficiency (Wendt et al., 2003) as well as cell proliferation (Grayson et al., 2008). Bioreactors can be used to improve nutrition of the cells located in the deep areas of the constructs during the culture period. With the use of an appropriate bioreactor system, different stress protocols (such as shear) can be applied on bone construct. There are three main commonly used bioreactor systems in bone tissue engineering: spinner flask, rotating wall and perfusion system.

\subsubsection{Spinner flask}

This bioreactor is a commonly used system in bone tissue engineering (for review see Ichinohe et al., 2008; Sikavitsas et al., 2002). It is composed of a vessel containing culture medium in which the tissue construct is suspended through a wire. A rotating magnetic bar causes the culture medium to agitate (Andrew et al., 2011). This system is more efficient in terms of bone differentiation compared with static and rotating wall culture systems. In spite of this positive point, the spinner flask possesses a deficiency regarding construct nutrition (Sikavitsas et al., 2002). One way to improve nutrient and waste product transport in and out of the construct is to increase the amount of rotation in the magnetic bar but this may lead to increased turbulent flow which in turn increases shear stress on the construct. It should be mentioned that although shear stress produced in the bioreactor has a positive influence on bone differentiation and mineralization (Bancroft et al., 2002, 2003; Bilodeau et al., 2006), exceeded stress may cause cellular damage. For this reason, there must always be a balance between nutrient transport efficiency and shear stress within the spinner flask.

\subsubsection{Rotating wall bioreactors}

This type of bioreactor is composed of two cylinders. The smaller cylinder is a stationary one inside the system and provides for gas exchange, while the outer one rotates. The cellseeded scaffold moves freely in the medium between these two cylinders (Andrew et al., 2011; Sikavitsas et al., 2002). It is believed that this system is not a very good culture system in bone tissue engineering due to the haphazard movement of the scaffold in the system, collision with the wall of the bioreactor and the low level of shear stress provided by this regime (Andrew et al., 2011).

\subsubsection{Perfusion bioreactors}

This system is a widely-used bioreactor in bone tissue engineering (for review see Bancroft et al., 2003; Gomes et al., 2003; Grayson et al., 2008; Sikavitsas et al., 2005). This bioreactor is 
composed of a perfusion cartridge connected to a pump and a medium reservoir through a tubing circuit. The perfusion cartridge surrounds the scaffold tightly, thus the medium cannot flow around the scaffold so it perfuse directly through the scaffold (Andrew et al., 2011). There are various types of this bioreactor. Those commonly used in bone tissue engineering include the flow perfusion culture bioreactor (for review see Bancroft et al., 2002, Gomes et al., 2003; Grayson et al., 2008; Sikavitsas et al., 2005), radial channel perfusion system (Grayson et al., 2008) and direct perfusion bioreactors (for review see Janssen et al., 2006a, 2006b, 2010). Use of the perfusion bioreactor improves nutrient and waste product transport within the construct. Cell loading efficiency is also improved in these systems since they are designed in such a way that the flow direction is repeatedly changed. Moreover, shear stress produced in this bioreactor enhances osteogenic differentiation of the loaded cells.

\subsection{Vascularization}

Bone construct usually encounters nutritional limitation due to a lack of microvasculature which occurs at two stages, during in vitro culture and the early days after implantation. As previously described, in vitro nutritional limitations can somewhat be improved with the application of an appropriate bioreactor system. To overcome nutritional limitation during the early days of implantation several strategies have been developed with the objective of inducing angiogenesis inside the construct.

\subsubsection{Angiogenic growth factors}

One strategy is to use growth factors known to promote angiogenesis when fabricating bone construct. According to the literature, angiogenic growth factors include VEGF (MayrWohlfart et al., 2002; Deckers et al., 2000), FGF (Saadeh et al., 2000), BMP-2, endothelin-1 (ET-1) (Von Schroeder et al., 2003; Bouletreau et al., 2002a), PDGF-BB (Bouletreau et al., 2002b), IGF and TGF-beta (Bouletreau et al., 2002b; Saadeh et al., 1999). VEGF has a direct effect on angiogenesis whereas the others exert their effect indirectly through regulation of VEGF secretion. Although VEGF plays a pivotal role in angiogenesis, unfortunately high doses of this recombinant protein are necessary to reach an optimal level of angiogenesis (Barralet et al., 2009).

\subsubsection{Design and architecture of the scaffold}

Design and architecture of a bone scaffold facilitates blood vessel formation in the fabricated construct. For example, nano/micro fiber combined scaffolds have been shown to promote endothelial cell migration and organization into capillary-like structures within the scaffold (Santos et al., 2008 as cited in Marina et al., 2010). The inclusion of a network with vasculature geometry in a biocompatible polymer using microfabrication techniques has been reported as an alternative way to create vessel-like structures in scaffolds. It should be mentioned that such methods are commonly used in developing a vasculature tree in soft organs rather than hard tissues such as bone (Marina et al., 2010).

\subsubsection{Co-culture system}

Since endothelial cells are able to establish microcapillary-like structures, the use of them in bone construct can be considered an alternative strategy to promote vessel formation inside the construct. For this purpose endothelial progenitor cells (EPCs) from bone marrow may 
be preferred. There are two types of EPCs, early and late (Veleva et al., 2008). Early cells appear within 4-7 days in culture and exhibit some endothelial as well as monocytic properties with restricted proliferative capacity. In contrast, late cells are those that appear 2-3 weeks after culture initiation and keep their expansion potential for a long time. According to investigations, while early cells contribute in neovascularization indirectly through cytokines and matrix metalloproteinase-8 (MMP-8) secretion, late cells contribute to vessel formation as building blocks as well as through MMP-2 secretion (Yoon et al., 2005, as cited in Marina et al., 2010).

\subsubsection{Microsurgery strategies}

Microsurgery techniques offer another approach to create blood vessel inside bone construct. Two of the most popular microsurgery methods for creating vascularized bone construct include flap fabrication and the creation of an arteriovenous loop (Kneser et al., 2006). In flap fabrication, bone construct including the scaffold, cells and growth factors pretransplants in a rich vascular bed (i.e., muscle) from which some blood vessels grow into the construct (Scheufler et al., 2008; Polykandriotis et al., 2007). Donor-site morbidity and two surgical interventions are two disadvantages of this method (Ren et al., 2008). In the arteriovenous loop method, vascularization of the porous scaffold is performed by implantation of an arterovenous loop around the construct (Kneser et al., 2006).

\section{Bone regeneration promoted by MSC-based bone constructs}

As mentioned earlier, large bone defects need clinical intervention for regeneration. For this purpose bone construct fabricated using tissue engineering principles is considered as a promising choice. Different types of bone constructs will be described followed by some examples in which MSC-based bone constructs have been used to regenerate bone defects in either animal models or humans.

\subsection{Types of bone construct based on constituting components}

Past investigations regarding bone regeneration have used the following constructs which differed in terms of their constituting elements: scaffold, cells, scaffold/growth factor, scaffold/cells, scaffold/cells/growth factor and scaffold/DNA. Scaffold alone is more suitable for small bone defects and usually comprised of tricalcium phosphate ceramics. Cell constructs involve the administration of MSCs in an injectable form with or without genetic manipulation. Scaffold/growth factor constructs are constructs in which growth factors are linked chemically or physically to a carrier or scaffold. Scaffold/MSCs constructs are the most frequently used one in tissue engineering and many studies have been designed with this model. Sometimes the scaffold/MSC construct contains transfected cells and this indeed is a combination of gene therapy and tissue engineering. Scaffold/cells/growth factor construct, on the other hand are rarely used. An excellent example of such construct is Gronthos' study (see below). Finally, the scaffold/DNA construct involves loading a scaffold by a DNA construct, usually in the form of plasmid DNA (Bonadio et al., 1999).

\subsection{MSC-based bone construct transplantation in animal models}

Before clinical application, a newly developed bone construct should be tested in animal models in term of its functionality. By pre-clinical studies scientists understand whether 
regeneration occurs due to the presence of MSCs in bone constructs or the osteoconductive/osteoinductive properties of the scaffold/growth factor. Among different preclinical models, large bone defect models are more commonly used since they are the type of defects problematic in the field of orthopedics as well as maxillofacial surgery (for review sees Perka et al., 2000). Various worldwide animal and clinical studies have been undertaken to cure this type of bone disease. Following are some examples of animal model studies that have used MSC-based constructs.

\subsubsection{MSCs alone}

An example of the application of MSCs in an animal bone defect model is a study conducted by Tsuda et al. who used MSCs transfected with BMP-2 to improve an osteoporetic disorder of aged rats (Tsuda et al., 2005).

\subsubsection{Scaffold/MSCs}

The application of bone constructs that consist of scaffold/MSCs is a common strategy to heal large bone defects, also referred to as critical sized defects in animal models. In most studies bioceramics are the biomaterial of choice. Kadiyala et al. have used autologous bone marrow-derived MSCs seeded onto ceramic scaffolds to regenerate an 8-mm experimentally-created defect in the rat femora. After eight weeks, bone formation was detected in the defective area (Kadiyala et al., 1997b). Similar animal studies have also been reported for canine and sheep models using scaffold/MSCs constructs (For review see Arinzeh et al., 2003; Kon et al., 2000). Application of varying ceramics in different ratios would be very crucial for fabricating a good construct. For example, Buruder et al. have fabricated MSC-based scaffolds comprised of 35\% beta tricalcium phosphate and 65\% hydroxyapatite which was implanted in a 21-mm experimentally-created segmental defect in the canine femur. They observed good integration of the construct with the host bone (Bruder et al., 1998). Using ceramic biomaterials we have also conducted some investigations. According to our studies, the use of rat MSCs in conjunction with natural scaffolds (i.e., Bio-Oss or human deproteinized and decellularized bone tissue) could enhance bone regeneration in rat calvarial defects more than platelet-rich plasma treatment (Khojasteh et al., 2009). In another study, we have compared the bone regeneration capacity of HA/TCP/MSCs with Bio-Oss/MSC constructs. Our results have shown the enhanced bone regeneration potential of HA/TCP/MSCs construct in a canine full-thickness alveolar defect model (Jafarian et al., 2008) compared with Bio-Oss/MSCs constructs.

Other research groups have studied the regenerative role of MSCs in combination with polymeric scaffolds in animal bone defects. For example, in a study by Holy et al., $1.2 \mathrm{~cm}$ bone defects in a rabbit femur were regenerated by using MSCs-loaded PLGA scaffolds. Their results have shown significant bone regeneration in MSC-based PLGA scaffolds compared with PLGA alone (Holy et al., 2003).

The composite scaffold/MSCs construct has also been tested in animal bone defects. For example, Diao et al. have manufactured a construct comprised of umbilical cord blood MSCs seeded on composite scaffold consisting of hydroxyapatite, PLLA and collagen. The composite, then, was implanted subcutaneously into SCID mice. Twelve weeks later, wellpromoted bone formation was observed in histological sections (Diao et al., 2009).

MSCs derived from sources other than bone marrow have been successfully applied to regenerate bone defects in combination with scaffolds. For example, the construct made of 
porous cylindrical PLA scaffolds and autologus adipose-derived stem cells have been reported to successfully regenerate skull defects in New Zealand white rabbits (Bella et al., 2008). Similarly, Jang et al. have noted the efficiency of construct comprised of beta TCPs and canine umbilical cord blood MSCs in canine cortical defect regeneration (Jang et al., 2008).

\subsection{MSC- based bone construct in clinical trials}

The ultimate objective of elaborating bone construct using principles of tissue engineering is to find an appropriate substitute for autologous bone graft which is considered the golden standard for regeneration of bone defects. The excellent regenerating effects of autologous bone graft may be related to its osteoconductive, osteoinductive and osteogenic capacities. Constructs fabricated by engineering principles using all three main building blocks have potentially all components necessary for real representation of autologous bone graft.

In bone construct, MSCs can be present either in an undifferentiated or differentiated state. Using MSCs as undifferentiated cells may have the disadvantage of their unwanted differentiation into non-bone cells where they are supposed to generate osteogenic cells. On the other hand, transplantation of MSCs as fully differentiated cells would be an alternative way to deliver cells into a bone defect. This requires long-term culture of the cells which is undesirable in a cell therapy strategy. Both strategies have been used in clinical trials.

At the moment, multiple clinical trials have been accomplished on human problematic bone lesions. Several others are ongoing and registered at http://clinicaltrials.gov, the official clinical trials website. In this regard, Royan Institute has registered a number of clinical trials regarding nonunion fractures, delayed union, bone cyst and distraction osteogenesis, using MSC-based bone constructs. In the following section some accomplished trials will be noted which are categorized according to the composition of the construct used.

\subsubsection{MSCs alone}

One well known example of the use of MSCs alone to regenerate osteogenic defects is in the treatment of osteogenesis imperfecta (OI), a heterogenous group of inherited disorders. Horwitz et al. have reported a trial in which allogenic bone marrow cells (from HLAidentical or single- antigen-mismatched siblings) have been intravenously infused into children with severe OI. According to their findings, there have been signs of improvement after transplantation as they observed a reduced number of osteocytes, linearly organized osteoblasts, lamellar bone formation as well as mineralization in the trabecular bones of affected children. Although this study demonstrated osteoblastic differentiation of MSCs, the lack of reliable controls and the absence of a long follow up period were the weak points of this clinical study (Horwitz et al., 1999). To fulfill this trial, Horwitz continued his study in another project in 2001 in which seven children with OI were selected. Five received cell therapy while two were in the control group. Six months after transplantation, growth acceleration was observed in the treated group in comparison with control children (Horwitz et al., 2001).

Another example of MSCs injection is with tibial achondroplasia and pseudoarthrosis in which distraction osteogenesis is necessary. To accomplish this, in vitro osteogenic differentiated marrow MSCs accompanied by platelet-rich plasma were injected into the distracted callus. After a period of time, healing was observed in treated patients (Kitoh et al., 2004). 


\subsubsection{Scaffold/MSCs/growth factor}

Constructs consisting of three components have rarely been utilized to regenerate human bone defects. An example is the work by Gronthos who has tried to regenerate 7-cm length mandibular defect generated due to tumor resection in a 56 year old patient. In this study, he designed a hollow titanium mesh, filled it with hydroxapatite, recombinant human BMP7 and MSCs, and transplanted it into the patient's lathismus dorsi muscle in order to encourage ectopic bone formation and blood vessel ingrowth. Seven weeks later, vascularized bone construct was removed and implanted into the patient's mandible. Four weeks post-transplantation, the mandible was functional and the patient could chew food (Gronthos, 2004).

\subsubsection{Scaffold/MSCs}

Scaffold/MSCs constructs are commonly used constructs in most clinical trials. There are several examples of such approaches in the literature. One such example is the work by Quarto et al. who have designed bone marrow MSC-loaded hydroxyapatite scaffolds to regenerate $7-\mathrm{cm}$ length human bone defects. Two months after transplantation, a large callus formed in the defect site with integration of the construct into host bone (Quarto et al., 2001). In a similar study, Morishita et al. have published successful bone tissue engineering approaches in the treatment of bone tumors by the implantation of authologous MSCsloaded hydroxyapatite scaffold (Morishita et al., 2006). Similarly Marcacci et al. have prepared constructs using autologous MSCs and hydroxyapatite scaffold, and have transplanted them into long bone defects in humans. Their trial was prominent since they had a prolonged follow up of 6-7 years. Using this method, they could detect good integration of the loaded scaffolds with surrounding bone, new vascular ingrowth and new bone formation inside the scaffold. Recovery of limb function was also reported and maintained after the 6-7 year follow up (Marcacci et al., 2007).

\section{Conclusion}

Bone constructs elaborated with tissue engineering principles are a promising substitute for autologous bone graft and have long been considered the golden standard for repair of large bone defects. Autologus bone graft owes its excellent repair effects to three crucial properties of osteoinduction, osteoconduction and osteogenesis. The building blocks that are used to fabricate bone construct impart three key properties as autologous bone graft (cells impart osteogenic property, scaffold cause osteoconductive and osteoinductive capacity and growth factors give osteoinductive potential). However, before tissue-engineered bone construct are to be routinely used in the clinic setting instead of bone grafts, several issues must be addressed. Although application of MSCs as cellular material facilitates the construct fabrication, there is still some issue with MSC preparation. MSC propagation is largely dependent on fetal bovine serum. Furthermore, natural bone is a composite of nano hydroxyapatite particles with collagen nanofibers which impart the tissue's unique properties. Unfortunately developing a scaffold with similar properties is still challenging. Finally, perhaps the main challenge in the field of bone tissue engineering is formation of blood vessels inside the fabricated constructs. Several strategies including the addition of angiogenic growth factors and cells to the construct, angiogenic design and architecture of bone scaffold, and microsurgery techniques have been proposed to promote angiogenesis 
inside the constructs. However, there is no reliable, reproducible and practical strategy in this developing field.

\section{References}

Andrew, B., Yeatts, J., Fisher, P. (2011). Bone tissue engineering bioreactors: Dynamic culture and the influence of shear stress. Bone, Vol.48,pp.(171-181).

Anita, H., Undale, M.B., Westendorf, J.J., Yaszemski, M.J., Sundeep Khosla, M.D. (2009). Mesenchymal Stem Cells for Bone Repair and Metabolic Bone Diseases, Mayo Clinical Proceeding. Vol. 84, NO.10, pp.(893-902).

Bancroft, G.N., Sikavitsast, V.I., van den Dolder, J., Sheffield, T.L., Ambrose, C.G., Jansen, J.A.(2002). Fluid flow increases mineralized matrix deposition in 3D perfusion culture of marrow stromal osteloblasts in a dose-dependent manner. Proc Natl Acad Sci U SA, Vol.99,pp.(12600-5).

Bassi, E.J., Aita, C.A.M., Câmara, N.O.S. (2011). Immune regulatory properties of multipotent mesenchymal stromal cells: Where do we stand?. World Journal of Stem Cells, Vol. 3, N.1, pp.(1-8).

Behraves, E., Yasko, A.W., Engel, P.S., Mikos, A.G. (1999). Synyhetic biodegradable polymers for orthopedic applications. Clinical Orthopedic related Research, Vol. 367, Pp. (S118-129).

Bella, C.D., Farlie, P. \& Penington, A.J.( 2008). Bone regeneration in a rabbit critical-sized skull defect using autologous adipose-derived cells. Tissue Engineering A, Vol.14, pp.(483-90).

Bilodeau, K., Mantovani, D. (2006). Bioreactors for tissue engineering: focus on mechanical constraints. A comparative review. Tissue Engineering, Vol.12,pp.(2367-83).

Bouletreau, P. J., Warren, S. M., Spector, J. A., Peled, Z. M., Gerrets, R. P., Greenwald, J. A. M., Longaker, T. (2002a). Plastic Reconstruction Surgery,Vol.109,pp.(2384-).

Bonadio, J., Smiley, E., Patil, P., Goldstein, S. (1999). Localized, direct plasmid gene delivery in vivo: prolonged therapy results in reproducible tissue regeneration. Nature Medicine, Vol.5,pp.(753-9).

Bouletreau, P. J., Warren, S. M., Spector, J. A., Steinbrech, D. S., Mehrara, B. J., Longaker, M. T. (2002b). Plastic Reconstruction Surgery. Vol.110, pp.(139-148).

Bruder, S.P., Jaiswal, N., Haynesworth, S.E. (1997). Growth kinetics, Self-renewal, and the osteogenic potential of purified human mesenchymal stem cells during extensive subcultivation and following cryopreservation. Journal of Cell Biochemistry, Vol. 64, pp.(278_294).

Bruder, S.P., Kraus, K.H., Goldberg, V.M., Kadiyala, S. (1998). The effect of implants loaded with autologous mesenchymal stem cells on the healing of canine segmental bone defects. Journal of Bone and Joint Surgery, Vol.80, pp.(985-96).

Bruder, S.P., Fox, B.S. (1999). Tissue engineering of bone: cell based strategies. Clinical Orthopedie, Vol. 367, pp.( S68-83).

Buttery, L.D., Bourne, S., Xynos, J.D., Wood, H., Hughes, F.J., Hughes, S.P., Episkopou, V., \& Polak, J.M.( 2001). Differentiation of osteoblasts and in vitro bone formation from murine embryonic stem cells. Tissue Engineering,Vol. 7, pp. (89-99)

Caplan, A.I. (1994). The mesengenic process. Clinical Plastic Surgery, Vol. 21, pp.(429-435). 
Carpio, L., Gladu, J., Goltzman, D., Rabbani, S.A. (2001). Induction of osteoblast differentiation indexes by PTHrP in MG-63 cells involves multiple signaling pathways. American Journal of Physiology Endocrinology and Metabolism, Vol. 281, pp. (489-99).

Chapekar, M.S. ( 2000). Tissue engineering: challenges and opportunities: J Biomed Mater Res, Vol. 53, pp.(617-620)

Chen,F.M., Zhao,Y.M., Wu,H., Deng, Z.H., Wang, Q.T., Zhou, W., Liu, Q., Dong, G.Y., Li, K., $\mathrm{Wu}, \mathrm{Z} . \mathrm{F} ., \mathrm{Jin}, \mathrm{Y}$. (2006). Enhancement of periodontal tissue regeneration by locally controlled delivery of insulin-like growth factor-I from dextran-co-gelatin microspheres, J. Control. Release, Vol.114, pp.( 209-222).

Choi, K.M., Seo, Y.K., Yoon, H.H., Song, K.Y., Kwon, S.Y., Lee, H.S., Park, J.K.(2008). Effect of ascorbic acid on bone marrow-derived mesenchymal stem cell proliferation and differentiation. Journal of Bioscience and Bioengineering, Vol. 105, pp. (586-94).

Coelho, M.J, Fernandes, M.H.(2000). Human bone cell cultures in biocompatibility testing. Part II: effect of ascorbic acid, beta-glycerophosphate and dexamethasone on osteoblastic differentiation. Biomaterial, Vol. 21, pp.(1095-102).

Colter, D.C., Sekiya, I., \& Prockop, D.J.( 2001). Identification of a subpopulation of rapidly self-renewing and multipotential adult stem cells in colonies of human marrow stromal cells. Proc.Natl Acad. Sci. USA. Vol. 98, pp.(7841-5)

Deckers, M.L., Karperien, M., van der Bent, C.,Yamashita, T., Papapoulos, S.E., Lowik, C.W.G.M. (2000). Endocrinology, Vol. 141,pp.(1667-1674).

de Boer, J., Siddappa, R., Gaspar, C., van Apeldoorn, A., Fodde, R., van Blitterswijk, C. ( 2004). Wnt signaling inhibits osteogenic differentiation of human mesenchymal stem cells. Bone, Vol. 34, pp. (818-26).

Diao, Y., Ma, Q., Cui, F. \& Zhong, Y.( 2009). Human umbilical cord mesenchymal stem cells: osteogenesis in vivo as seed cells for bone tissue engineering. Journal of Biomedical Materials Research, Vol.91,pp.(123-131).

Diefenderfer, D.L., Osyczka, A.M., Reilly, G.C., Leboy PS. (2003). BMP responsiveness in human mesenchymal stem cells. Connective Tissue Research, Vol. 44, Suppl. 1,pp. (305-11).

Di Nicola, M., Carlo-Stella, C., Magni, M., Milanesi, M., Longoni, P.D., Matteucci, P., Grisanti, S., Gianni, A.M. (2002). Human bone marrow stromal cells suppress Tlymphocyte proliferation induced by cellular or nonspecific mitogenic stimuli. Blood,Vol.99, pp.(3838-3843).

Diptiman, C., Kumar S., \& Ponnazhagan, S. (2010). Therapeutic Potential of Adult Bone Marrow-Derived Mesenchymal Stem Cells in Diseases of the Skeleton. Journal of Cellular Biochemistry, Vol.111, pp.(249-257).

Dominici, M., Le Blanc, K., Mueller, I., Slaper-Cortenbach, I., Marini, F., Krause, D., Deans, R., Keating, A., Prockop, D.j., Horwitz, E.(2006). Minimal criteria for defining multipotent mesenchymal stromal cells. The International Society for Cellular Therapy position statement.Cytotherapy, Vol. 8, pp.(307-315).

Dragoo, J.L., Samini, B., Zhu, M., Hame, S.L., Thomas, B.J., Lieberman, J.R., Hedrick, M.H., Benhaim, P. (2003).Tissue-engineered cartilage and bone using stem cells from human infrapatellar fat pads. Journal of Bone Joint Surgery, Vol. 85, pp.(740-747). 
Ducy, P., Schinke, T., Karsenty, G.(2000b). The osteoblast: a sophisticated fibroblast under central surveillance. Science, Vol.289, pp. (1501-4).

Ehrhart, N.P., Hong, L., Morgan, A.L., Eurell, J.A., Jamison, R.D. (2005). Effect of transforming growth factor-beta1 on bone regeneration in critical-sized bone defects after irradiation of host tissues. American Journal ofVeterinary Research, Vol.66,pp.( 1039-1045).

Eslaminejad, M.B., Mirzadeh, H., Nickmahzar, A., Mohamadi, Y. (2007). Bone differentiation of marrow- derived mesenchymal stem cells using beta- tricalcium phosphatealginate- gelatin hybrid scaffolds. Journal of Tissue Engineering \& Regenerative Medicine, Vol.1,No.6, pp.( 417-424).

Eslaminejad, M.B., Talkhabi, M., Zainali, B. (2008) Effect of Lithium chloride on proliferation and bone differentiation of rat marrow-derived mesenchymal stem cells in culture. Iranian Journal of Basic Medical Sciences, Vol. 3, pp.(143-151).

Evans, M.J., \& Kaufman, M.H. (1981). Establishment in culture of pluripotential cells from mouse embryos. Nature,Vol. 292, pp. (154-6).

Feng, L., Bronson, S., \& Niyibizi, C. (2010). Derivation of Murine Induced Pluripotent Stem Cells (iPS) and assessment of Their Differentiation Toward Osteogenic Lineage. Journal of Cellular Biochemistry. Vol. 109. pp. (643-652)

Friedenstein, A.J., Piatetzky-Shapiro, II., Petrakova, K.V. (1966). Osteogenesis in transplants of bone marrow cells. Journal of Embryology and Experimental Morphology, Vol. 16, pp. (381-90).

Friedenstein, A.J. (1973). Detrimined and inducible osteogenic precursure cells. Hard Tissue Growth, Repair and Remineralization.pp:(169-185).

Friedenstein, A. J, Deriglasova, U.F., Kulagina, N.N., Panasuk, A.F., Rudakowa, S.F., Luria, E.A., \& Ruadkow, I.A. ( 1974). Precursors for fibroblasts in different populations of hematopoietic cells as detected by the in vitro colony assay method. Experimental Hematology. Vol. 2,pp.(83-92).

Fukumoto, T., Sperling, J.W., Sanyal, A., Fitzsimmons, J.S., Reiholz, G.G., Conover, C.A., O'Driscoll, S.W. (2003). Combined effects of insulin-like growth factor1- and transforming growth factor-beta1 on periosteal mesenchymal stem cells during chondrogenesis in vitro. Osteoarthritis Cartilage, Vol. 11, pp.( 55-64).

Galmiche, M.C., Koteliansky, V.E., Briere, J., Herve, P., Charbord, P.(1993) .Stromal cells from human long-term marrow cultures are mesenchymal cells that differentiate following a vascular smooth muscle differentiation pathway. Blood, Vol. 1, No. 82, pp. (66-76).

Gladstone, M.W., McDermott, D., Cooke. (1995). Implants for cranioplasty, Otolaryngol, Clin. North Am, Vol.28, No. 2, pp.(381-400).

Gomes, M.E., Sikavitsas, V.I., Behravesh, E., Reis, R.L., Mikos, A.G. (2003). Effect of flow perfusion on the osteogenic differentiation of bone marrow stromal cells cultured on starchbased three-dimensional scaffolds. Journal of Biomedical Material Research A, Vol.67A, pp.(87-95).

Gori, F., Thomas, T., Hicok, K.C., Spelsberg, T.C., Riggs, B.L. (1999). Differentiation of human marrow stromal precursor cells: bone morphogenetic protein-2 increases OSF2/CBFA1, enhances osteoblast commitment, and inhibits late adipocyte maturation. Journal of Bone and Mineral Research, Vol. 14, pp.(1522-35). 
Grayson, W.L., Bhumiratana, S., Cannizzaro, C., Chao, P.H.G., Lennon, D.P., Caplan, A.I.(2008). Effects of initial seeding density and fluid perfusion rate on formation of tissueengineered bone. Tissue Engineering A, Vol.14,pp.(1809-20).

Gronthos, S. (2004). Reconstruction of human mandible by tissue engineering. Lancet, Vol.3,pp.(735-736).

Gruber, R., Kandler, B., Fuerst, G., Fischer, M.B., Watzek, G. (2004). Porcine sinus mucosa holds cells that respond to bone morphogenetic protein (BMP)-6 and BMP-7 with increased osteogenic differentiation in vitro. Clinical Oral Implants Research, Vol. 15, pp. (575-80).

Villalona, G.A., Udelsman, V.B., Duncan, D.R., McGillicuddy, E., Sawh-Martinez, R.F., Hibino, N., Painter, C., Mirensky, T., Erickson, B., Shinoka, T., and Breuer, C.K.(2010). Cell-Seeding Techniques in Vascular Tissue Engineering, Tissue engineering:part B, Vol.16,No. 3, pp.(341-350).

Haasper, C., Zeichen, J., Meister, R., Krettek, C., Jagodzinski, M.(2008). Tissue engineering of osteochondral constructs in vitro using bioreactors. Injury, 39S1,pp.(S66-S76).

Habraken, W.J.E.M., Wolke, J.G.C., Jansen, J.A. (2007). Ceramic composites as matrices and scaffolds for drug delivery in tissue engineering, Advanced drug delivery reviews, Vol. 59, pp.(234-248).

Hanna, J., Wernig, M., Markoulaki, S., Sun, C.W., Meissner, A., Cassady, J.P., Beard, C., Brambrink, T., Wu, L.C., Townes, T.M., Jaenisch, R.( 2007). Treatment of sickle cell anemia mouse model with iPS cells generated from autologous skin. Science, Vol. 318, pp.(1920-1923).

Heary, R.F., Schlenk, R.P., Sacchieri, T.A., Barone, D., Brotea, C. (2002). Persistent iliac crest donor site pain: independent outcome assessment. Neurosurgery, Vol.50, pp.(510516).

Heath, C.A. (2000). Cells for tissue engineering. Trends in Biotechnology. Vol. 18, pp. (17-19).

Horwitz, E.M., Prockop, D.J., Fitzpatrick, L.A., Koo, W.W., Gordon, P.L., Neel, M., Sussman, M., Orchard, P., Marx, J.C., Pyeritz, R.E., Brenner, M.K. (1999). Transplantability and therapeutic effects of bone marrow-derived mesenchymal cells in children with osteogenesis imperfecta. Nature Medicine, Vol.5, pp.(309-313).

Horwitz, E.M., Prockop, D.J., Gordon, P.L., Koo, W.W., Fitzpatrick, L.A., Neel, M.D., McCarville, M.E., Orchard, P.J., Pyeritz, R.E., Brenner, M.K.( 2001). Clinical responses to bone marrow transplantation in children with severe osteogenesis imperfecta. Blood, Vol.97,pp.(1227-1231).

Holy, C.E., Fialkov, J.A., Davies, J.E., Shoichet, M.S. (2003). Use of a biomimetic strategy to engineer bone. Journal of Biomedical Materials Research A, Vol.65,pp.(447-53).

Holzer, G., Einhorn, T.A., Majeska, R.J. (2002).Estrogen regulation of growth and alkaline phosphatase expression by cultured human bone marrow stromal cells. Journal of Orthopedic Research, Vol. 20, pp. (281-8).

Hou, C.H., Yang, R.S., Hou, S.M. (2005). Hospital-based allogenic bonebank-10-year experience. Journal of Hospital Infections, Vol. 59, pp.(41-45).

Hsu, S.H., Tsai, I.J., Lin, D.J., Chen, D.C. (2005).The effect of dynamic culture conditions on endothelial cell seeding and retention on small diameter polyurethane vascular grafts. Med Eng Phys, Vol.27, pp. (267-272). 
Huss, R., Hong, D.S., McSweeney, P.A., Hoy, C.A., Deeg, H.J. (1995). Differentiation of canine bone marrow cells with hematopoietic characteristic from an adherent stromal cell precursors. Proc Natl Acad Sci USA, Vol. 92, pp.(748-752).

Ichinohe, N., Takamoto, T., Tabata, Y. (2008). Proliferation, osteogenic differentiation, and distribution of rat bone marrow stromal cells in nonwoven fabrics by different culture methods. Tissue Engineering A, Vol.14, pp.(107-16).

Isenmann, S., Cakouros, D., Zannettino, A., Shi, S., Gronthos, S. (2007). hTERT transcription is repressed by Cbfa1 in human mesenchymal stem cell populations. Journal of Bone and Mineral Research, Vol.22, pp. (897-906).

Ishaug-Riley, S.L., Crane, G.M., Gurlek, A., Miller, M.J., Yasko, A.W., Yaszemski, M.J., Mikos, A.G. (1997). Ectopic bone formation by marrow stromal osteoblast transplantation using poly(DL-lactic-co-glycolic acid) foams implanted into the rat mesentery. Journal of Biomedical Materials Research, Vol. 36, pp.(1-8).

Jafarian, M., Eslaminejad, M.B., Khojasteh, A., Mashhadi Abbas, F, Dehghan, M.M., Hassanizadeh, R., Houshmand, B. (2008). Marrow- derived mesenchymal stem cells- directed bone regeneration in dog mandible: a comparison between biphasic calcium phosphate and natural bone mineral. Oral Surg Oral Med Oral Pathol Oral Radiol Endod, Vol.105,No. 5, pp.(14-24).

Jaiswal, R.K., Jaiswal, N., Bruder, S.P., Mbalaviele, G., Marshak, D.R., Pittenger, M.F. (2000). Adult human mesenchymal stem cell differentiation to the osteogenic or adipogenic lineage is regulated by mitogen-activated protein kinase. Journal of Biological Chemistry, Vol. 275, pp. (9645- 52).

Jang, B.J., Byeon, Y.E., Lim, J.H., Ryu, H.H., Kim, W.H., Koyama, Y., Kikuchi, M., Kang, K.S., \& Kweon, O.K. ( 2008). Implantation of canine umbilical cord blood-derived mesenchymal stem cells mixed with beta-tricalcium phosphate enhances osteogenesis in bone defect model dogs. Journal of Veterinology Science, Vol.9, pp.(387-93).

Jankowsk, R.J., Deasy, B.M., Huard, J. (2002). Muscle-derived stem cells. Gene therapy, Vol. 9, pp. (642-647).

Janssen, F.W., Oostra, J., van Oorschot, A., van Blitterswijk, C.A. (2006a). A perfusion bioreactor system capable of producing clinically relevant volumes of tissueengineered bone: in vivo bone formation showing proof of concept. Biomaterials,Vol.27,pp.(315-23).

Janssen, F.W., Hofland, I., van Oorschot, A., Oostra, J., Peters, H., van Blitterswijk, C.A.(2006). Online measurement of oxygen consumption by goat bone marrow stromal cells in a combined cell-seeding and proliferation perfusion bioreactor. Journal of Biomedical Material Research A , Vol.79A,pp.(338-48).

Janssen, F.W., van Dijkhuizen-Radersma, R., Van Oorschot, A., Oostra, J., de Bruijn, J.D., Van Blitterswijk, C.A. (2010). Human tissue-engineered bone produced in clinically relevant amounts using a semi-automated perfusion bioreactor system: a preliminary study. Journal of Tissue Engineering and Regenerative Medicine, Vol.10, No.4,pp.(12-24).

Jiang, Y., Jahagirdar, B.N., Reinhardt, R.L., Schwartz, R.E., Dirk, Keene, C., Ortiz-Gonzalez, X.R., Reyes, M., Lenvik, T., Lund, T., Blackstad, M., Du, J., Aldrich, S., Lisberg, A., Low, W.C., Largaespada, D.A., Verfaillie, C.M. (2002). Pluripotency of mesenchymal stem cells derived from adult marrow. Nature, Vol. 418, pp.(41-49). 
Kadiyala, S., Young, R.G., Thiede, M.A., Bruder, S.P. (1997a).Culture expanded canine mesenchymalstem cells possess osteochon drogenic potential in vivo and in vitro. Cell Transplant, Vol. 6, pp.(125-134).

Kadiyala, S., Jaiswal, N., Bruder, S.P. (1997b). Culture-expanded, bone marrowderived mesenchymal stem cells regenerate a critical-sized segmental bone defect. Tissue Engineering, Vol.3,No.2, pp.(173-185).

Kain, M.S., Einhorn, T.A. (2005). Recombinant human bone morphogenetic proteins in the treatment of fractures, Foot Ankle Clinics, Vol.10, pp.(639-650).

Kato, T., Kawaguchi, H., Hanada, K., Aoyama, I., Hiyama, Y., Nakamura, T., Kuzutani, K., M. Tamura, T., Kurokawa, K. Nakamura. (1998).Single local injection of recombinant fibroblast growth factor-2 stimulates healing of segmental bone defects in rabbits. Journal of Orthopedical Research, Vol.16, pp.( 654-659).

Kawaguchi, H., Kurokawa, T., Hanada, K., Hiyama, Y., Tamura, M., Ogata, E., Matsumoto, T. (1994). Stimulation of fracture repair by recombinant human basic fibroblast growth factor in normal and streptozotocin diabetic rats. Endocrinology, Vol.135,pp.( 774-781).

Kawaguchi, J., Mee, P.J., \& Smith, A.G.( 2005). Osteogenic and chondrogenic differentiation of embryonic stem cells in response to specific growth factors. Bone, Vol. 36, pp. (758-69).

Kenny, S.M., Buggy, M. (2003). Bone cements and fillers: a review. Journal of Material Science and Material Medicine, Vol.14, pp.(923-938).

Khojasteh, A., Eslaminejad, M.B., Nazarian, H.(2008). Mesenchymal stem cells enhance bone regeneration in rat calvarial critical size defect more than platelete rich plasma. Oral Surg, Oral Med, Oral Pathol, Oral Radiol, Endodont, Vol.106, pp.(356-362).

Kimelman, N., Pelled, G., Gazit, Z., Gazit, D. (2006). Applications of gene therapy and adult stem cells in bone bioengineering. Regenerative Medicine, Vol. 1, pp.(549-561).

Kirker-Head, C.A. (2000). Potential applications and delivery strategies for bone morphogenetic proteins, Adv. Drug Deliery. Reviews, Vol. 43,pp.(65-92).

Kitoh, H., Kitakoji, T., Tsuchiya, H., Mitsuyama, H., Nakamura, H., Katoh, M., Ishiguro, N. (2004). Transplantation of marrow-derived mesenchymal stem cells and plateletrich plasma during distraction osteogenesis--a preliminary result of three cases. Bone, Vol.35, pp.(892-8).

Kleber, M., Sommer, L. (2004). Wnt signaling and the regulation of stem cell function. Current Opinions in Cell Biology, Vol.16, pp.(681-687).

Klyushnenkova, E., Mosca, J.D., Zernetkina, V., Majumdar, M.K., Beggs, K.J., Simonetti, D.W., Deans, R.J., McIntosh, K.R. (2005). T cell responses to allogeneic human mesenchymal stem cells: immunogenicity, tolerance, and suppression. Journal of Biomedical Sciences, Vol.12, pp.(47-57).

Kneser, U., Schaefer, D.J., Polykandriotis, E., Horch, V.J. (2006). Tissue engineering of bone : the surgeon's point of view. Journal of Cellular and Molecular Medicine, Vol.10,pp.( 719).

Koch, H., Jadlowiec, J.A., Campbell, P.G. (2005). Insulin-like growth factor-I induces early osteoblast gene expression in human mesenchymal stem cells. Stem Cells and Development, Vol. 14, pp. (621-31). 
Kretlow, J.D., Mikos, A.G. (2007).Mineralization of synthetic polymer scaffolds for bone tissue engineering. Tissue Engineering, Vol. 13, pp.(927-938).

Laffargue, P., Hildebrand, H.F., Rtaimate, M., Frayssinet, P., Amoureux, J.P., Marchandise, X. (1999). Evaluation of human recombinant bone morphogeneticprotein-2-loaded tricalcium phosphate implants in rabbits' bone defects.Bone, Vol. 25, pp.(55S-58S).

Lee S.H., Shin, H. (2007).Matrices and scaffolds for delivery of bioactive molecules in bone and,cartilage tissue engineering. Advanced Drug Delivery Reviews, Vol. 59, pp.(339359).

LeGeros, R.Z. (2002). Properties of osteoconductive biomaterials: calcium phosphates, Clin. Orthop. Relat. Res, Vol.395, pp.( 81-98).

Li, Y., Ma, T., Kniss, D.A., Lasky, L.C., Yang, S.T. (2001). Effects of filtration seeding on cell density, spatial distribution, and proliferation in nonwoven fibrous matrices. Biotechnol Prog, Vol.17, pp.(935-44).

Li, R.,Stewart, D.J., von Schroeder, H.P., Mackinnon, E.S., Schemitsch, E.H. (2009). Effect of cell-based VEGF gene therapy on healing a segmental bone defect. Journal of Orthopedic Research. Vol. 27, pp.(8-14).

Liu, Y., Titus, L., Barghouthi, M., Viggeswarapu, M., Hair, G., Boden, S.D. (2004). Glucocorticoid regulation of human BMP-6 transcription. Bone, Vol. 35, pp. (67381).

Liu, H., Kemeny, D.M., Heng, B.C., Ouyang, H.W., Melendez, A.J., Cao, T. (2006). The immunogenicity and immunomodulatory function of osteogenic cells differentiated from mesenchymal stem cells. Journal of Immunology, Vol. 176, pp.(2864-71).

Marcacci, M., Kon, E., Moukhachev, V. (2007). Stem cells associated with macroporous bioceramics for long bone repair: 6- to 7-year outcome of a pilot clinical study. Tissue Engineering, Vol.13, No.6, pp.(947-955).

Marina, I., Santos, Rui, L. Reis. (2010). Vascularization in Bone Tissue Engineering: Physiology, Current Strategies, Major Hurdles and Future Challenges. Macromolecular bioscience, Vol.10,pp.(12-27).

Massagué, J., Wotton, D. (2000). Transcriptional control by the TGF-beta/Smad signaling system. The EMBO Journal, Vol. 19, pp. (1745-54).

Matsuda, N., Lin, W.L., Kumar, N.M., Cho, M.I., Genco, R.J. (1992).Mitogenic, chemotactic, and synthetic responses of rat periodontal ligament fibroblastic cells to polypeptide growth factors in vitro, J. Periodontol., Vol.63,pp.( 515-525).

Mayr-Wohlfart, J., Waltenberger, H., Hausser, S., Kessler, K. P., Gunther, C., Dehio, Brenner R. E. (2002). Vascular endothelial growth factor stimulate chemotactic migration of primary human osteoblasts. Bone, Vol.30,pp.( 472-477).

Meyers, V.E, Zayzafoon, M., Douglas, J.T., McDonald, J.M. (2005). RhoA and cytoskeletal disruption mediate reduced osteoblastogenesis and enhanced adipogenesis of human mesenchymal stem cells in modeled microgravity. Journal of Bone and Mineral Research, Vol. 20, pp.(1858-66).

Middleton, J.C., Tipton, A.J. (2000). Synthetic biodegradable polymers as orthopedic devices. Biomaterials, Vol 23, pp. (2335-2346).

Miura, M., Grothos, S., Zhao, M., Lu, B., Fisher, L.W., Robery, P.G., Shi, S. (2003). Stem cells from human exfoliated decidusus teeth. Proceed nation acad Sci USA, Vol. 100, pp.( 5807-5812). 
Morishita, T., Honoki, K., Ohgushi, H., Kotobuki, N., Matsushima, A., Takakura, Y. (2006). Tissue engineering approach to the treatment of bone tumors: three cases of cultured bone grafts derived from patients' mesenchymal stem cells.Artifitial Organs, Vol.30,pp.(115-8).

Nakagawa,N., Yasuda, H., Yano, K., Mochizuki, S., Kobayashi, N., Fujimoto,H., Shima, N., Morinaga, T., Chikazu, D., Kawaguchi, H., Higashio,K.(1999). Basic fibroblast growth factor induces osteoclast formation by reciprocally regulating the production of osteoclast differentiation factor and osteoclastogenesis inhibitory factor in mouse osteoblastic cells. Biochemical and Biophysical Research Communications, Vol.265, pp.(158-163).

Nakajima, T., Iizuka, H., Tsutsumi, S., Kayakabe. M., Takagishi, K. (2007). Evaluation of posterolateral spinal fusion using mesenchymal stem cells: differences with or without osteogenic differentiation. Spine, Vol.32, pp.(2432-2436).

Nasseri, B.A., Pomerantseva, I., Kaazempur-Mofrad, M.R.Sutherland, F.W., Perry, T., Ochoa, E. (2003). Dynamic rotational seeding and cell culture system for vascular tube formation. Tissue Engineering,Vol.9, pp.( 291-299).

Nishida, J., Shimamura, T. (2008). Methods of reconstruction for bone defect after tumor excision: a review of alternatives. Med Sci Monit, Vol. 14,pp. (107-113).

Noth, U., Osyczka, A.M., Tuli, R., Hickok, N.J., Danielson, K.G., Tuan, R.S. (2002). Multilineage mesenchymal differentiation of human trabecular bone-derived cells. Journal of Orthopedics Research, Vol. 20, pp.(1060-1069).

Perka, C., Schultz, O., Spitzer, R.S., Lindenhayn, K., Burmester, G.R., Sittinger. M.(2000). Segmental bone repair by tissue-engineered periosteal cell transplants with bioresorbable fleece and fibrin scaffolds in rabbits. Biomaterials, Vol.21,pp.(1145-53).

Persidis, A.(1999). Tissue engineering. Nat Biotechnol, Vol. 17, pp.(508-510)

Petrakova, K.V., Tolmacheva, A.A., Fridenstein, A.J. (1963).Bone formation occuring in bone marrow transplantation in diffusion chambers, Biull Eksp Biol Med, Vol. 56, pp. (8791).

Pittenger, M.F., Mackay, A.M., Beck, S.C., Jaiswal, R.K., Douglas, J.D.( 1999). Multilineage potential of adult human mesenchymal stem cells. Science, Vol. 284, pp.(143-7).

Porter, J.R., Ruckh, T.T., \& Popat, K.C. (2009). Bone Tissue Engineering: A Review in Bone Biomimetics and Drug Delivery Strategies. American Institute of Chemical Engineers Biotechnol. Prog, Vol. 25, pp.(1539-1560).

Potten, C.S., Loffler, M. (1990). Stem cells: attributes, cycles, spirals, pitfalls and uncertainties. Lessons for and from the crypt. Development, Vol. 110,pp. ( 10011020).

Prockop, D.J.(1997). Marrow stromal cells as stem cells for nonhematopoietic tissues. Science. Vol. 276, pp.(71-74).

Quarto, R., Mastrogiacomo, M., Cancedda, R., Kutepov, S.M., Mukhachev, V., Lavroukov, A., Kon, E., Marcacci, M. (2001). Repair of large bone defects with the use of autologous bone marrow stromal cells. National English Journal of Medicine,Vol.1, pp.(385-386).

Rickard, D.J., Kazhdan, I., Leboy, P.S. (1995). Importance of 1,25-dihydroxyvitamin D3 and the nonadherent cells of marrow for osteoblast differentiation from rat marrow stromal cells. Bone, Vol. 16, pp.(671-8). 
Rasmusson, I., Le Blanc, K., Sundberg, B., Ringdén, O. (2007). Mesenchymalstem cells stimulate antibody secretion in human B cells. Scand J Immunol, Vol. 65, pp.( 336343).

Ripamonti, U., Ma, S.S., van den Heever, B., Reddi, A.H. (1992). Osteogenin, a bone morphogenetic protein, adsorbed on porous hydroxyapatite substrata, induces rapid bone differentiation in calvarial defects of adult primates. Plastic Reconstruction Surgery, Vol.90, pp.(382-393).

Roh, J.D., Nelson, G.N., Udelsman, B.V., Brennan, M.P., Lockhart, B., Fong, P.M., LopezSoler, R.I., Saltzman, W.M.,and Breuer, C.K. (2007).Centrifugal seeding increases seeding efficiency and cellular distribution of bone marrow stromal cells in porous biodegradable scaffolds. Tissue Engineering, Vol.13,pp.( 2743-2749).

Ross, R., Everett, N.B., Tyler, R. (1970). Wound healing and collagen formation. The origin of the wound fibroblast studied in parabiosis. Journal of Cell Biology, Vol. 44, pp. (645654).

Saadeh, P.B., Mehrara, B.J., Steinbrech, D.S., Spector, J.A., Greenwald, J.A., Chin, G.S., Ueno, H., Gittes, G.K., Longaker, M.T. (2000). Mechanisms of fibroblast growth factor-2 modulation of vascular endothelial growth factor expression by osteoblastic cells. Endocrinology, Vol.141, pp. (2075-2083).

Scaglione, S.,Wendt, D., Miggino, S., Papadimitropoulos, A., Fato, M., Quarto, R. (2008). Effects of fluid flow and calcium phosphate coating on human bone marrow stromal cells cultured in a defined 2D model system. J Biomed Mater Res A,Vol.86, pp.(411-9).

Schmidmaier, G., Lucke, M., Schwabe, P., Raschke, M., Haas, N.P., Wildemann, B. (2006). Collective review: bioactive implants coated with poly(D,Llactide) and growth factors IGF-I, TGF-beta1, or BMP-2 for stimulation of fracture healing, Journal LongTerm Effects in Medical Implants, Vol.16, pp.(61-69).

Scutt, A., Bertram, P. (1995). Bone marrow cells are targets for the anabolic actions of prostaglandin E2 on bone: induction of a transition from nonadherent to adherent osteoblast precursors. Journal of Bone and Mineral Research, Vol. 10, pp.(474-87).

Seong, J.M., Kim, B.C., Park, J.H., Kwon, I.K., Mantalaris, A., \& Hwang Y.S. (2010). Stem cells in bone tissue engineering. Biomedical Materials,Vol. 5,pp. (1-15)

Sherley, J.L., Stadler, P.B., Johnson, D.R. (1995). Expnession of the wild-type P53 antioncogene induces guanine nucleotide-dependent stem cell division kinetics. Proc.Natl.Acad.sci.USA, Vol. 2, pp.(136-140).

Sikavitsas, V.I., Bancroft, G.N., Mikos, A.G. (2002). Formation of three-dimensional cell/ polymer constructs for bone tissue engineering in a spinner flask and a rotatingwall vessel bioreactor. Journal of Biomedical Material Research, Vol.62,pp.(136-48).

Sotiropoulou, P.A., Perez, S.A., Gritzapis, A.D., Baxevanis, C.N., Papamichail, M. (2006). Interactions between human mesenchymal stem cells and natural killer cells. Stem Cells, Vol. 24, pp.(74-85).

Spinella-Jaegle, S., Rawadi, G., Kawai, S., Gallea, S., Faucheu, C., Mollat, P., Courtois, B., Bergaud, B., Ramez, V., Blanchet, A.M., Adelmant, G., Baron, R., Roman-Roman, S. (2001).Sonic hedgehog increases the commitment of pluripotent mesenchymal cells into the osteoblastic lineage and abolishes adipocytic differentiation. Journal of Cell Science, Vol. 114, pp. (2085-94). 
Swetha, M., Sahithi, K., Moorthi, A., Srinivasan, N., Ramasamy, K., Selvamurgan, N. (2010)Biocomposites containing natural polymers and hydroxyapatite for bone tissue engineering. International journal of biological macromolecules, Vol. 47,pp.(1-4).

Thomson, J.A., Itskovitz-Eldor, J., Shapiro, S.S., Waknitz, M.A., Swiergiel, J.J., Marshall, V.S., Jones, J.M. (1998). Embryonic stem cell lines derived from human blastocysts. Sciences. Vol. 282, pp.(1145-1147).

Tsuda, H., Wada, T., Yamashita, T., Hamada, H.( 2005). Enhanced osteoinduction by mesenchymal stem cells transfected with a fiber-mutant adenoviral BMP2 gene. $J$ Gene Med, Vol. 7,pp.(1322-1334).

Tu, Q., Valverde, P., Chen, J. (2006). Osterix enhances proliferation and osteogenic potential of bone marrow stromal cells. Biochemical and Biophysic Research Communication. Vo. 341, pp. (1257-1265)

Undale, A.H., Westendorf, J.J., Yaszemski, M.J., Khosla, S. (2009). Mesenchymal Stem Cells for Bone Repair and Metabolic Bone Diseases. Mayo Clinical Proceedings, Vol. 84, No. 10, pp. (893-902).

Urist,M.R.(1965). Bone: formation by autoinduction, Science, Vol. 150, pp.(893-899).

van Wachem, P.B., Stronck, J.W., Koers-Zuideveld, R., Dijk, F., and Wildevuur, C.R. (1990).Vacuum cell seeding: a new method for the fast application of an evenly distributed cell layer on porous vascular grafts. Biomaterials, Vol.11,pp.(602-606).

Veleva, A. N., Heath, D.E., Cooper, S.L., Patterson, C. (2008). Selective endothelial cell attachment to peptide-modified terpolymers. Biomaterials, Vol.29,pp.(3656- 3661).

von Schroeder, H. P., Veillette, C. J., Payandeh, J., Qureshi, A., Heersche, J. N. (2003). Endothelin-1 promotes osteoprogenitor proliferation and differentiation in fetal rat calvarial cell cultures. Bone, Vol. 33,pp.(673-684).

Wang, M. (2006). Composite scaffolds for bone tissue engineering. American journal of Biochemistry and Biothecnology, Vol. 2, pp. (80-84)

Wendt, D., Marsano, A., Jakob, M., Heberer, M., Martin, I.(2003). Oscillating perfusion of cell suspensions through three-dimensional scaffolds enhances cell seeding efficiency and uniformity. Biotechnol Bioeng,Vol.84,pp.(205-14).

Wernig, M., Meissner, A., Foreman, R., Brambrink, T., Ku, M., Hochedlinger, K., Bernstein, B.E., Jaenisch, R.( 2007). In vitro reprogramming of fibroblasts into a pluripotent ES-cell-like state. Nature, Vol. 448. Pp. (318-324).

Wickham, M.Q., Erickson, G.R., Gimble, J.M., Vail, T.P., Guilak, F. (2003). Multipotent stromal cells derived from infrapatellar fat pad of knee. Clinical Orthopedics, pp. (196-212).

Williams, C., and Wick, T.M. (2004). Perfusion bioreactor for small diameter tissueengineered arteries. Tissue Engineering, Vol.10,pp.( 930-941).

Woll, N.L, Heaney, J.D., \& Bronson, S.K.( 2006). Osteogenic nodule formation from single embryonic stem cell-derived progenitors. Stem Cell Development, Vol. 15, pp.(86579).

Yamaguchi, A., Komori, T., Suda, T. (2000). Regulation of osteoblast differentiation mediated by bone morphogenetic proteins, hedgehogs, and Cbfa1. Endocrine Reviews, Vol. 21, pp. (393-411).

Yang, Y.G., Sykes, M. (2007). Xenotransplantation: current status and a perspective on the future. Nature Review Immunology, Vol. 7, pp.(519-531). 
Yoon, B.S., Lyons, K.M. (2004). Multiple functions of BMPs in chondrogenesis. Journal of Cellular Biochemistry, Vol.93,pp.( 93-103).

Young, R.G., Butler, D.L., Weber, W., Caplan, A.I., Gordon, S.L., Fink, D.J. (1998). Use of mesenchymal stem cells in a collagen matrix for Achilles tendon repair. Journal of Orthopedics Research, Vol. 16, pp. (406-413).

Zandi, M., Mirzadeh, H., Urch, H., Eslaminejad, M.B., Bagheri, F., Mivechi, H. (2010). Biocompatibility evaluation of nano- rod hydroxyapatite/ gelatin coated with nano- Hap as a novel scaffold using mesenchymal stem cell. Journal of Biomedical Materials Research A, Vol.92, pp.(1244- 55).

Zaragosi, L.E., Ailhaud, G., Dani, C. (2006). Autocrine FGF2 signaling is critical for selfrenewal of human multipotent adipose-derived stem cells. Stem Cells, Vol.24, pp.(2412-2419). 


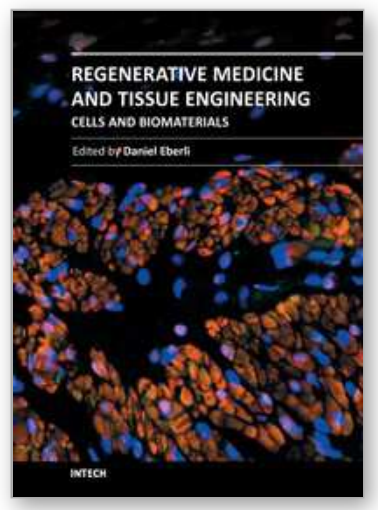

\author{
Regenerative Medicine and Tissue Engineering - Cells and \\ Biomaterials \\ Edited by Prof. Daniel Eberli
}

ISBN 978-953-307-663-8

Hard cover, 588 pages

Publisher InTech

Published online 29, August, 2011

Published in print edition August, 2011

Tissue Engineering may offer new treatment alternatives for organ replacement or repair deteriorated organs. Among the clinical applications of Tissue Engineering are the production of artificial skin for burn patients, tissue engineered trachea, cartilage for knee-replacement procedures, urinary bladder replacement, urethra substitutes and cellular therapies for the treatment of urinary incontinence. The Tissue Engineering approach has major advantages over traditional organ transplantation and circumvents the problem of organ shortage. Tissues reconstructed from readily available biopsy material induce only minimal or no immunogenicity when reimplanted in the patient. This book is aimed at anyone interested in the application of Tissue Engineering in different organ systems. It offers insights into a wide variety of strategies applying the principles of Tissue Engineering to tissue and organ regeneration.

\title{
How to reference
}

In order to correctly reference this scholarly work, feel free to copy and paste the following:

Mohamadreza Baghaban Eslaminejad and Faezeh Faghihi (2011). Mesenchymal Stem Cell-Based Bone Engineering for Bone Regeneration, Regenerative Medicine and Tissue Engineering - Cells and Biomaterials, Prof. Daniel Eberli (Ed.), ISBN: 978-953-307-663-8, InTech, Available from:

http://www.intechopen.com/books/regenerative-medicine-and-tissue-engineering-cells-andbiomaterials/mesenchymal-stem-cell-based-bone-engineering-for-bone-regeneration

\section{INTECH}

open science | open minds

\section{InTech Europe}

University Campus STeP Ri

Slavka Krautzeka 83/A

51000 Rijeka, Croatia

Phone: +385 (51) 770447

Fax: +385 (51) 686166

www.intechopen.com

\section{InTech China}

Unit 405, Office Block, Hotel Equatorial Shanghai

No.65, Yan An Road (West), Shanghai, 200040, China

中国上海市延安西路65号上海国际贵都大饭店办公楼 405 单元

Phone: +86-21-62489820

Fax: $+86-21-62489821$ 
(C) 2011 The Author(s). Licensee IntechOpen. This chapter is distributed under the terms of the Creative Commons Attribution-NonCommercialShareAlike-3.0 License, which permits use, distribution and reproduction for non-commercial purposes, provided the original is properly cited and derivative works building on this content are distributed under the same license. 